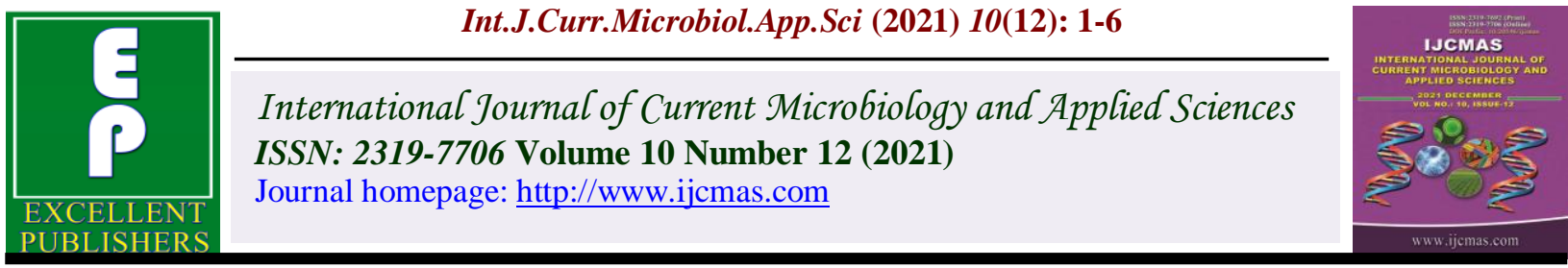

\title{
Investigation of Some Pathogenic Bacteria Isolated from Fresh Water Fish, Khartoum State, Sudan
}

\author{
Mohammed Abass Albashire Mohammedali ${ }^{1}$, Mohamed Ismail Fangama ${ }^{2 *}$, \\ Siham Elias Suliman ${ }^{1}$ and Mohammed AbdeLSalam Abdalla ${ }^{1}$ \\ ${ }^{1}$ College of Veterinary Medicine (SUST) \\ ${ }^{2}$ Ministry of health, Qatar Public Health Department, Qatar \\ *Corresponding author
}

\section{Keywords}

Fresh water fish, Pathogenic bacteria, Sudan

\section{Article Info}

Received: 02 November 2021 Accepted: 30 November 2021 Available Online: 10 December 2021

\section{A B S T R A C T}

Freshwater fish play a major role in feeding of people near to Nile river specially in Sudan. This study was conducted to investigate the pathogenic bacteria infected fish in Khartoum state. A total of 50 fish were examined at fish market in Khartoum city. The types of fish were 19 Nile tilapia (Oreochromis niloticus), 18 Synodontis (Synodontis schall), 3 Nile puffer (Tetraodon lineatus), 4 Bagrus catfishes (Bagrus bayad) and 6 Nile Perch (Lates niloticus). Fish subjected to postmortem and bacteriological examination. The common lesions were darkness of the skin, hemorrhage in the fins base, eyes and different parts of the body, abdominal distention, congested in gills and increasing in mucous secretion. The Postmortem findings showed white serous fluid in the abdominal cavity and sometimes tinged with blood and pale or congested liver and kidney. Three swab samples obtained from each fish from gill, liver and kidney. The bacteriological isolation and identification samples revealed that the prevalence of bacterial pathogens among naturally infected freshwater fishes were: Streptococcus iniae (21;14\%), Staphylococcus aureus (47;31.3\%), Salmonella spp (44;29.3\%), Escherichia coli $(44 ; 29.3 \%)$ and Pseudomonas spp $(17 ; 11.3 \%)$. In conclusion the bacteria identified in this study are considered as zoonotic bacteria of significant economic importance. It is recommended to raise the awareness of fish workers and consumers for possible biological hazard.

\section{Introduction}

Fish has become an increasingly important source of protein and other element necessary for the maintenance of health. Many species of fish normally live in fresh water rivers. Fish is one of the most highly perishable food products in which quality deterioration occurring rapidly during handling and storage that limits the shelf life of the product (Haile and Getahun, 2018).

Fish meat has many advantages includes: cheap, easy digestion, source of proteins and 
high element values, thus this fish susceptible to various bacterial pathogens. Bacteria are single cell microscopic organisms occurring in different sizes and forms (Abowei and Briyai., 2011). These forms include rods, spherical, spiral, coma and filamentous shape. Bacterial organisms have cell wall, which maintains the cell integrity (Bassey, 2011).

Some causing disease and other saprophyte, but there are many factors affecting of fish diseases and these are fish age, sex, species, breed, stress, contamination (Haenen, 2013) and climate variation(Safirska, 2018).

In the case of poor hygiene, the contamination of fish and fish products may increase due to unsanitary procedures, the rotation of the assigned duties of workers, and airborne microorganisms during packing of the product (Novotny et al., 2004).

Topically acquired zoonoses from fish are not numerous, but individual cases may be severe. Topically acquired zoonoses are vastly underreported worldwide. This is partly the result of not recognising that fish can be the source of zoonotic infection, and partly because zoonotic agents derived from fish are still nonnotifiable in most countries (Haenen, 2013). The objective of this paper was to investigate pathogenic bacteria in fish in Khartoum state.

\section{Materials and Methods}

\section{Study area}

This study was conducted in Khartoum state is a capital of Sudan and its divided into Omdurman, Khartoum and Bahri. Omdurman district contains three localities and these are; Omdurman, Karrary and Ombeda (Annual report; 2017). Almawrda market is a big market for sealing of fish in Omdurman locality.

\section{Sample Collection}

A total of 50 fish were subjected to postmortem and bacteriological examination were 19 Nile tilapia (Oreochromis niloticus), 18 Synodontis (Synodontis schall), 3 Nile puffer (Tetraodon lineatus), 4 Bagrus catfishes (Bagrus bayad) and 6 Nile Perch (Latesniloticus). Postmortem examination were carried out according to (Schaperclaus et al., 1992). A sterile cotton swabs were rubbed on the lesions in gills, liver and kidney.

Gram's stain method was used according to the method described by Austin and Austin (2007) for morphological characterestics of bacteria. Samples were cultured on Tryptic Soya broth (TSB) (Difco, Detroit, MI, USA) supplemented with $3 \% \mathrm{NaCl}$ which was used for the growth of some suspected isolates prior to plating. Nutrient agar medium $0.5 \%$ which is supplemented with $3 \% \mathrm{NaCl}$ which was used for the preservation of all isolated strains as well as for the detection of bacterial motility and also nutrient slope agar for detection of pigments produced by microorganism. Biochemical tests were used for identification of bacteria (Oxoid, 2006; Barrow and Felthman, 2003).

\section{Statistical Analysis}

Statistical analysis of data was performed using SPSS (Statistical Package for the Social Sciences) version 20.0 (SPSS inc. Chicago, USA) by using frequencies.

\section{Results and Discussion}

The common lesions observed in fish were darkness of the skin, hemorrhage in the fins base, eyes and different parts of the body, abdominal distention, congestion and hemorrhage under the mouth and operculum (figure 1,2). As shown in table 1 the infection was high in Nile tilapia (42.1\%), While there 
was no infection in Nile puffer $(0 \%)$. From the results there were two species of gram positive and these were Streptococcus iniae and Staphylococcus aureus, While gram negative were three species and these were salmonella spp, Escherichia coli and Pseudomonas spp (Table 2). Table 3 revealed that Staphylococcus aureus, Salmonella spp and Escherichia coli were predominant in the gill, liver and kidney, whereas Streptococcus iniae and Pseudomonas spp were lowered in these organs. Gill more infected organ with Streptococcus iniae than other isolates (42.9\%), but liver more infected by Salmonella spp (38.6\%) and kidney more infected by Pseudomonas spp (47.1\%).

The common lesion in this study figure (1) in agreement with Hamouda, et al., (2019). Who said that the post mortem changes may be attributed to the septicemia caused by bacteria and their virulence genes. These pathogenic bacteria might secrete extracellular products as aerolysin, haemolysin, cytotoxic toxins, Slayers and extracellular enzymes as gelatinase, proteases, lipases, hyaluronidase, nuclease hypuricase, elastase, C5a-ase, CAMP factors and aggregation substance. The secretion of these substances from bacteria possess cytolytic, enterotoxic and haemolytic effects responsible for pathogenesis (Hamouda, et al., 2019).

In this study, fish showed many changes indicating the presence of the disease fig (1, $2)$. Generally, the infected fish show many signs of disease (Bruno and wood, 1994; Adeyemo, 2003; Haj-Ali, 2010; Hassan et al., 2010). The isolated bacteria in the present results were from the famous species of fish (table 1) and the most infected type of fish was Nile tilapia (42.1\%) because represented the main fish in the area of study (Paperna, 1996).

Table.1 Number of healthy and infected fish examined (postmortem examination) in the Khartoum state, Sudan

\begin{tabular}{|c|c|c|c|c|}
\hline No & Fish breed & Total & $\begin{array}{c}\text { No of healthy } \\
\text { fish }\end{array}$ & No of diseased fish \\
\hline $\mathbf{1}$ & Nile tilapia (Oreochromis niloticus) & 19 & $11(57.9 \%)$ & $8(42.1 \%)$ \\
\hline $\mathbf{2}$ & Synodontis (Synodontis schall) & 18 & $14(77.8 \%)$ & $4(22.2 \%)$ \\
\hline $\mathbf{3}$ & Nile puffer (Tetraodon lineatus) & 3 & $3(100 \%)$ & $0(0 \%)$ \\
\hline $\mathbf{4}$ & Bagrus catfishes (Bagrus bagrus) & 4 & $3(75 \%)$ & $1(25 \%)$ \\
\hline $\mathbf{5}$ & Nile Perch (Lates niloticus) & 6 & $5(83.3 \%)$ & $1(16.7 \%)$ \\
\hline & Total & 50 & $36(72 \%)$ & $14(28 \% \%)$ \\
\hline
\end{tabular}


Table.2 Identification of different isolates from fish $(n=50)$ in Khartoum state

\begin{tabular}{|c|c|c|c|c|c|}
\hline $\begin{array}{c}\text { Biochemical } \\
\text { tests }\end{array}$ & Strept.iniae & Staph. aureus & Salmonella spp & E.coli & Pseudomonas spp \\
\hline Gram- stain & $+v e$ & $+v e$ & -ve & -ve & -ve \\
\hline Motility test & Non motile & Non motile & Non motile & $\begin{array}{l}\text { Non } \\
\text { motile }\end{array}$ & Motile \\
\hline Oxidase & - & - & - & - & + \\
\hline Catalase & - & + & + & + & + \\
\hline Coagulase & - & + & + & - & - \\
\hline Urease & - & + & - & - & - \\
\hline O-F & $\mathrm{F}$ & $\mathrm{F}$ & $\mathrm{F}$ & $\mathrm{F}$ & $\mathrm{O}$ \\
\hline Indole & - & - & - & + & - \\
\hline Citrate & - & + & + & - & + \\
\hline Xylose & + & - & + & + & - \\
\hline Fructose & + & + & + & + & - \\
\hline Maltose & + & + & + & + & - \\
\hline $\begin{array}{c}\text { Lactose } \\
\text { fermentation }\end{array}$ & + & + & - & - & - \\
\hline $\begin{array}{c}\text { Non lactose } \\
\text { fermentation }\end{array}$ & - & - & + & + & + \\
\hline $\begin{array}{c}\text { Glucose } \\
\text { fermentation }\end{array}$ & + & + & + & + & - \\
\hline $\begin{array}{c}\text { Sucrose } \\
\text { fermentation }\end{array}$ & + & + & + & + & + \\
\hline Mannitol & - & + & + & & + \\
\hline Haemolysis & $\mathrm{BH}$ & $\mathrm{BH}$ & $\mathrm{BH}$ & $\mathrm{BH}$ & $\mathrm{BH}$ \\
\hline \multirow{4}{*}{$\begin{array}{c}\text { Kliglar Iron } \\
\text { Agar(KIA): } \\
\text { BUH } \\
\text { Gas } \\
\text { H}_{2} \mathrm{~S}\end{array}$} & & & & & \\
\hline & & ND & & Acid/Acid & Alk/Alk \\
\hline & & - & + & + & + \\
\hline & & - & + & - & - \\
\hline
\end{tabular}

$+=$ Positive, $-=$ Negative, $\beta \mathrm{H}=$ Beta Haemolysis, $\mathrm{ND}=$ Not detected.

Table.3 Distribution of isolates in fish organs ( $\mathrm{n}=50$ fish from each three samples obtained=150) in Khartoum.

\begin{tabular}{|c|c|c|c|c|c|}
\hline Isolates & -ve result & +ve result & \multicolumn{3}{|c|}{ +ve result in organs } \\
\hline Streptococcus iniae & & & Gill & Liver & kidney \\
\hline Staphyllococus aureus & 129 & 21 & $9(42.9 \%)$ & $7(33.33)$ & $5(23.8)$ \\
\hline Salmonella spp & 103 & 47 & $16(34 \%)$ & $14(29.8 \%)$ & $17(36.2)$ \\
\hline Escherichia coli & 106 & 44 & $13(29.6 \%)$ & $17(38.6 \%)$ & $14(31.8 \%)$ \\
\hline Pseudomonas spp & 133 & 44 & $13(29.6 \%)$ & $14(31.8 \%)$ & $17(38.6 \%)$ \\
\hline
\end{tabular}


Fig.1 Tilapia (Oreochromis niloticus): Congestion under the mouth and operculum (see arrow)

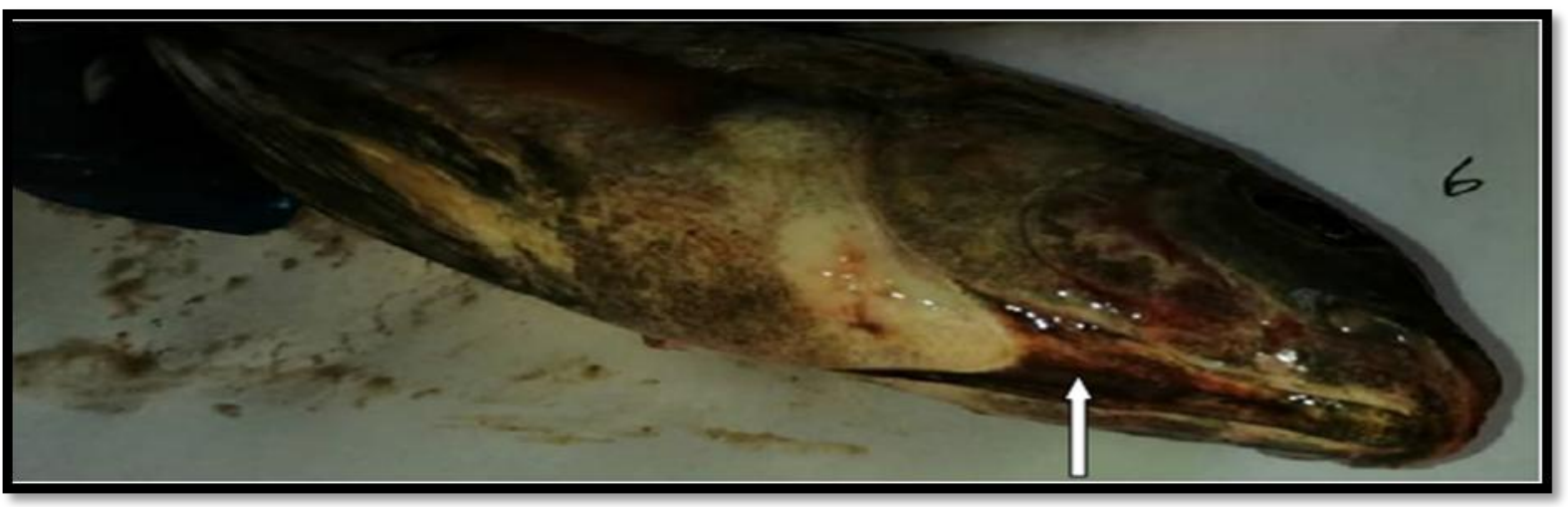

Fig.2 Tilapia(Oreochromis niloticus): Haemorrhage under the mouth and operculum(see arrow)

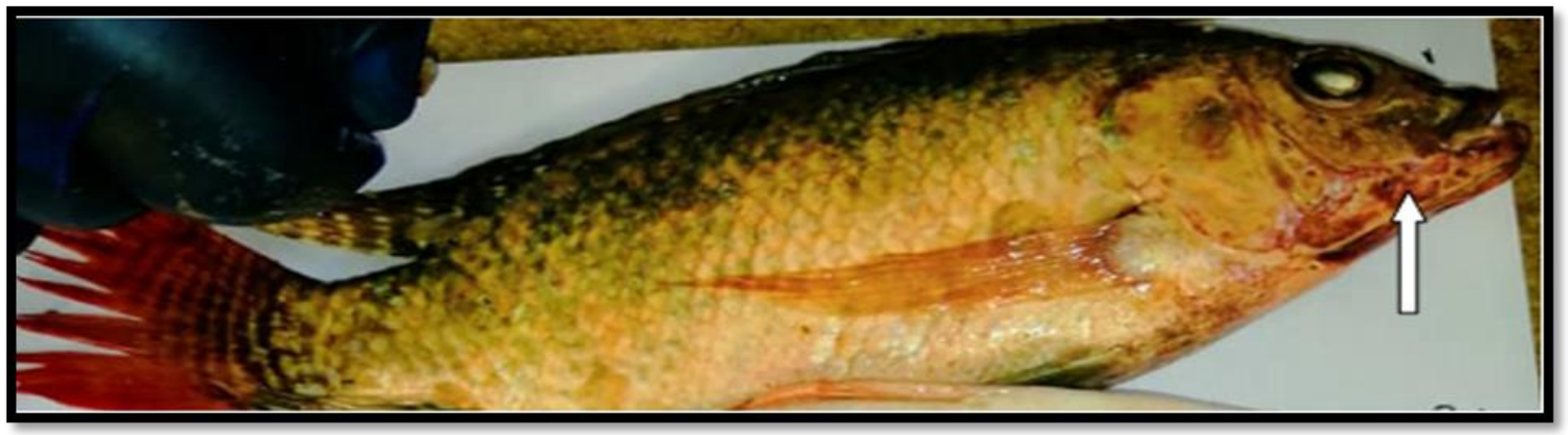

These bacteria are zoonotic and causing topical acquired infection or food born contamination (Haenen et al., 2013).

The most contamination bacteria (Table 2) was Staphyllococus aureus (31.3\%) contributed to high contamination of natural water than Salmonella (29.3\%), Escherichia coli (29.3\%), Streptococcus anae (14.0\%) and Pseudomonas (11.3\%) this is due to potential biological contamination of aquaculture products by these bacteria (WHO,1999, Huss et al., 2003, Nancy et al., 2021). Also all these pathogenic organisms were non motile, but Pseudomonas species was motile, oxidative and fermentable sucrose and mannitol (AbdelGawad et al., 2015.).

The presence of isolates (Table 3) in the gill, liver and kidney that help in increasing the load of bacteria in these organs (Inglis et al.,
1993). Fish infected pathogenic bacteria may affected many people contact fish as fisherman, fish handlers, fish cockers and fish consumers. Prevention from increasing interface between human and aquatic animals by decreasing the contact and consumption of safety seafood.

\section{References}

Abdel-Gawad FagrKh, Wedad E. Eweda, ElTaweelGamila E., Shehata Sawsan F., Abdel TawabI. Marwa (2015) Detection of Staphylococcus aureus from fish and water samples collected from Lake Qarun. International Journal of Scientific \& Engineering Research, Volume 6, Issue 8, August-2015 366 ISSN 2229-5518.

Abowei J. F. N. and Briyai O. F. (2011) A Review of Some Bacteria Diseases in Africa Culture Fisheries, Asian Journal of Medical Sciences 3(5): 206-217. 
Agnieszka Pękala-Safińska (2018) Contemporary Threats of Bacterial Infections in Freshwater Fish. Journal of veterinary research. 2018 Sep; 62(3): 261-267.

Annual report (2017). Ministry of Agriculture and Animal Resources Khartoum state, Sudan.

Austin B and Austin D A (2007). Bacterial Fish Pathogens, Diseases of Farmed and Wild Fish Fourth Edition, Praxis Publishing Ltd, Chichester, UK.

Barrow, G. I. and Feltham, R. K. A. (2003) (Own and Steal, Manual for the identification of medical bacteria. Third edition: Cambridge university press, $\mathrm{PP} 1-2$

Bassey, S. E.(2011).A Concise Dictionary of Parasitology. 1st Edn., Zetus Concepts, Port Harcourt, pp: 115, ISBN: 978-2954-40-3.

Haenen O. L. M; J. J. Evans and F. Berthe (2013) Bacterial infections from aquatic species: potential for and prevention of contact zoonoses, Rev. scientific technique Of. International Epizotiology, 2013, 32 (2),pp 497-507

Haile. Adanech Beshada and GetahunTemesgen Kassa (2018). Isolation and identification of Escherichia coli and Edwardsiella tarda from fish harvested for human consumption from Zeway Lake, Ethiopia, African Journal of Microbiology Research Vol. 12(20), pp. 476-480.

Hamouda Awatef Hamed, Eman Moustafa Moustafa, Mohamed Mamdouh Zayed (2019). Overview on the Most Prevailing Bacterial Diseases Infecting Oreochromis niloticus at Aswan Fish Hatchery, Egypt Advanced Animal Veterinary Science journal 7(11)pp: 950-961.

Huss H. H., Ababouch L. \& Gram L. (2003). -
Assessment and management of seafood safety and quality. FAO Fisheries Technical Paper 444. FAO, Rome. Available at: ftp://ftp.fao.

org/docrep/fao/006/y4743e/y4743e00.pdf (accessed on 14 June 2013).

Inglis, V.; Roberts, J. R.; Bromage, R. N. (1993). Fish diseases. First edition, Blackwell Science company, Ames, Iowastate, USA

Nancy Topi'c, ArijanaCenov, Slaven Jozi'c 2, Marin Glad 1, Diana Mance, DraženLuši'c, DamirKapetanovi'c, Davor Mance and Darija Vuki'cLuši'c(2021) Staphylococcus aureus - An Additional Parameter of Bathing Water Quality for Crowded Urban Beaches International Journal of Environment Research and Public Health 2021, 18, 5234

Novotny. L., L. Dvorska, A. Lorencova, V. Beran, I. Pavlik (2004), Fish: a potential source of bacterial pathogens for human beings Vet. Med. - Czech, 49, 2004 (9): 343-358

Oxoid, LTD. (2006). The oxoidmanual. Ninth edition. Oxoid limited, Wixel Road, Basingstoke, Hampshire.

Schäperclaus W, Kulow H, Schreckenbach K (1992). Infections abdominal dropsy. In: Schäperclaus W. (Ed.) fish disease, Akademie-Verlag, Berlin. 1: 401- 458.

World Health Organization (WHO) (1999). - Food safety associated with products from aquaculture: report of a joint FAO/NACA/WHO study group. WHO Technical Report Series 883. WHO, Geneva. Available at: www.who.int/foodsafety/ publications/fs_management/en/aquaculture. pdf (accessed on 1 June 2013).

\section{How to cite this article:}

Mohammed Abass Albashire Mohammedali, Mohamed Ismail Fangama, Siham Elias Suliman and Mohammed AbdeLSalam Abdalla. 2021. Investigation of Some Pathogenic Bacteria Isolated from Fresh Water Fish, Khartoum State, Sudan. Int.J.Curr.Microbiol.App.Sci. 10(12): 1-6. doi: https://doi.org/10.20546/ijcmas.2021.1012.001 